\title{
Considerations on infant mortality and its neonatal component
}

Approximately 3 million newborn infants die worldwide in their first month of life. One million of these deaths occur within the first 24 hours of birth. ${ }^{1}$

Neonatal mortality (NM) is defined as a death occurring in the first 28 days of life, whereas postneonatal mortality is that occurring between the end of the neonatal period and one year of life. A series of factors influence and determine mortality rate: biological, demographic, socioeconomic, cultural, environmental, geographic, and health care-related factors. The extent of their influence varies depending on the age of infants younger than one year old. ${ }^{2}$

Causes related to perinatal conditions predominate in NM, such as maternal health care, access to antenatal care visits, care provided during labor, and infant care during the first days of life.

NM during the first week of life, especially in the first three days, is mostly related to prematurity, low birth weight, neonatal asphyxia, respiratory distress, and birth defects (including heart disease and nervous system malformations), whereas, after the first week, half of the deaths are caused by neonatal sepsis., ${ }^{3,4}$

Approximately $61 \%$ of neonatal deaths occurred in 2014 in Argentina, as per the classification of reducible deaths conducted in 2011, account for deaths that could be prevented if efforts were made to improve the quality of mother and child care and to adjust health policies in accordance with needs. ${ }^{5}$ Such efforts include improving timely maternal care visits, advancing the number and quality of antenatal care visits, regionalizing perinatal care according to the level of care provided at the maternity centers with the adequate human and technological resources, warranting any mother or child gets the necessary referral timely and in due form, and ensuring the operation of the national network for the surgical correction of birth defects.

Besides, and at an international level, the Sustainable Development Goals (SDGs) adopted by the United Nations in 2015 include that of ensuring healthy lives and promoting well-being for all children. One of the objectives of SDG 3 aspires to end preventable deaths in newborn infants and children younger than 5 years of age by 2030 (Sustainable Development Goal 3). ${ }^{6}$
Although the infant mortality rate (IMR) in Argentina has decreased from $16.6 \%$ in 2000 to $10.8 \%$ in 2014 , the course of the reduction in NMR has been slower and is at $7.4 \%$, and accounts for more than two-thirds of IM composition. ${ }^{7}$ Besides, it has been observed that although IMR and NMR have also decreased in every Argentine jurisdiction, major inequalities have been recorded, which indicate a trend over time associated with a greater incidence of unmet basic needs. ${ }^{8}$

Moreover, in relation to adolescent pregnancies, $15.6 \%$ of deliveries occurred in Argentina in 2013 corresponded to mothers younger than 20 years of age; and the rate is above the national mean in 17 jurisdictions. Adolescent pregnancy is an indicator of inequality across jurisdictions: it accounts for $8.8 \%$ of deliveries in Buenos Aires City (CABA), whereas it accounts for $24.4 \%$ of all deliveries in Formosa and Chaco. The percentage of live NBIs born to adolescent mothers younger than 15 years old describes situations that may be related to child abuse and/ or gender-based violence, in addition to poor access to formal education and to sexual and reproductive health programs. ${ }^{9}$

In the CABA, the NMR has not decreased as expected over the past few years; the latest available statistical data indicate a strong association between poverty and infant mortality across the different CABA districts. It is worth noting that CABA records a component of births and deaths of children born to mothers who reside outside CABA, especially those living in Greater Buenos Aires population centers. To date, no study has been done to investigate this problem and any association in this regard remains unknown. It is necessary to become aware of where newborn infants are born and die in Argentina and determine any association with maternal age and place of residence.

In this issue, Meritano et al. assess the relationship among the place of maternal residence, the use of a health system subsector, and neonatal mortality rate in CABA in the 20112012 period. This was a population study based on reliable records. Authors analyzed data on birth rate and mortality rate according to the subsector of health used by the mother, which included the public, private and social security subsectors, and also provided very interesting data on the 
magnitude of this problem among mothers who live outside $C A B A$ but give birth in the CABA and for whom NMR is higher.

The article describes the importance of having reliable records and proposes a discussion on multi-sector efforts and the goals aimed at improving population access to health care and overcoming inequalities and social determinants of health.

Analyzing how to reduce neonatal mortality is a complex issue. And even more important, it is necessary to conduct a strict and urgent analysis on the quality of life and living conditions of infants surviving diseases in the neonatal period.

To conclude, I would like to quote a great Argentine physician and health expert, Ramón Carrillo, M.D.: "The right to health is among the most overlooked rights; however, it is the most transcendental right because it is related to an individual's dignity, community life, and national and international economy. It would not be too adventurous to say that a population's health is an essential condition for its social security and peace".

Adriana Aguilar, M.D. Assistant Editor aaguilar.publicaciones@sap.org.ar

http:/ /dx.doi.org/10.5546/aap.2016.eng.400

\section{REFERENCES}

1. Resumen ejecutivo El compromiso con la supervivencia infantil: Una promesa renovada. Informe sobre los progresos de 2014 [Internet]. [Accessed on: July 9 ${ }^{\text {th }}, 2016$ ]. Available at: http:/ / www.unicef.org/argentina/spanish/APR_Exec_ Summary_Final_SP_2014.pdf

2. Argentina. Ministerio de Salud de la Nación. Dirección de Estadísticas e Información en Salud. Definiciones y Conceptos en estadísticas de salud [Internet]. [Accessed on: July $\left.9^{\text {th }}, 2016\right]$. Available at: http: / / www.deis.gov.ar / definiciones.htm

3. Shankar MJ, Natarajan CK, Das RR, Agarwal R, et al. When do newborns die? A systematic review of timing of overall and cause-specific neonatal deaths in developing countries. J Perinatol 2016;36 Suppl 1:S1-S11.

4. Sociedad Argentina de Pediatría, UNICEF. Salud maternoinfanto-juvenil en cifras 2013. Diez principales causas de muerte en el período neonatal. República Argentina. 2011. Buenos Aires: UNICEF; 2013. [Accessed on: July 10 ${ }^{\text {th }}, 2016$ ]. Availableat:http://www.unicef.org/argentina/spanish/ salud_SapUnicef_cifras2013.pdf

5. Finkelstein JZ, Duhau M, Abeyá Gilardon E, Ferrario C, etal. Mortalidad infantilen Argentina. $3^{\text {a }}$ revisión de los criterios de reducibilidad. Arch Argent Pediatr 2015;113(4):352-8.

6. Organización Mundial de la Salud. Reducción de la mortalidad en la niñez. Respuesta mundial: Objetivo de Desarrollo Sostenible 3. Nota descriptiva N¹78. Ginebra: OMS; 2016. [Accessed on: July 9th, 2016]. Available at: http:/ / www.who.int/mediacentre/factsheets/fs178/es/

7. Argentina. Ministerio de Salud de la Nación. Indicadores Básicos 2015. [Accessed on: July 9 $\left.{ }^{\text {th }}, 2016\right]$. Available at: http:/ / deis.msal.gov.ar/wp-content/uploads/2016/01/ indiba2015.pdf

8. Buchbinder M. Mortalidad infantil y desigualdad socioeconómica en la Argentina. Tendencia temporal. Arch Argent Pediatr 2008;106(3):212-8.

9. Sociedad Argentina de Pediatría, UNICEF. Salud maternoinfanto-juvenil en cifras 2015. Buenos Aires: UNICEF; 2015 [Accessed on: July $\left.9^{\text {th }}, 2016\right]$. Available at: http://www. unicef.org/argentina/spanish/SALUD_Sap-Unicef_2015_ web.pdf 